\title{
Kanker Paru: Laporan Kasus
}

\author{
Junita Joseph, ${ }^{1}$ Linda W. A. Rotty ${ }^{2}$
}

\author{
${ }^{1}$ PPDS Bagian Ilmu Penyakit Dalam Fakultas Kedokteran Universitas Sam Ratulangi Manado \\ ${ }^{2}$ Bagian Ilmu Penyakit Dalam Fakultas Kedokteran Universitas Sam Ratulangi Manado \\ Email: josephjunita0@gmail.com
}

\begin{abstract}
In general, lung cancer is all kinds of malignancy of the lung. It consists of malignancy derived from the lung itself (primary) and from out of the lung (metastasis). Clinically, primary lung cancers are malignant tumors derived from bronchial epithelium (bronchial carcinoma). Lung cancer is the main cause of death due to malignancy worldwide. We reported a male of 55-yearold male diagnosed as lung cancer. Diagnosis was based on anamnesis, physical examination, and supporting investigations. Anamnesis included smoking for 10 years \pm 15 cigarettes/day and complaints of shortness of breath, coughing, chest pain radiating to the back, and significant weight loss. Physical examination revealed enlargement of the right supraclavicular gland and decreased breath sounds in the right lung at the fifth intercostal space. Thorax photo, thorax CTscan, and histopathological examination confirmed the diagnosis of lung cancer (adenocarcinoma). Chemotherapy was administered with a combination of gemcitabine-cisplatin regimens for 12 cycles. The prognosis of this patient was poor because the disease had reached stage 4 . However, the patient felt some clinical improvement after one month of chemotherapy.

Keywords: lung cancer
\end{abstract}

\begin{abstract}
Abstrak: Kanker paru dalam arti luas adalah semua penyakit keganasan di paru, mencakup keganasan yang berasal dari paru sendiri (primer) maupun keganasan dari luar paru (metastasis). Dalam pengertian klinis yang dimaksud dengan kanker paru primer adalah tumor ganas yang berasal dari epitel bronkus (karsinoma bronkus). Kanker paru merupakan penyebab utama kematian akibat keganasan di dunia Kami melaporkan sebuah kasus kanker paru pada seorang laki-laki berusia 55 tahun. Diagnosis ditegakkan berdasarkan anamnesis, pemeriksaan fisik, dan pemeriksaan penunjang yang meliputi adanya riwayat merokok (sigaret) selama 10 tahun sebanyak \pm 15 batang rokok/hari, dengan sesak nafas, batuk, nyeri dada menjalar sampai ke punggung, dan penurunan berat badan yang nyata. Pada pemeriksaan fisik didapatkan pembesaran kelenjar supraklavikular kanan dan suara nafas menurun pada paru kanan setinggi sela iga V. Pada pemeriksaan penunjang foto toraks, thorax CT-scan, dan histopatologik didapatkan hasil yang menyokong diagnosis kanker paru (adenokarsinoma). Pada pasien ini, telah diberikan penatalaksanaan kemoterapi dengan kombinasi regimen gemcitabine-cisplatin selama 12 siklus. Prognosis pasien ini buruk karena sudah sampai pada stadium 4 , namun dengan kemoterapi yang dijalani sampai saat ini selama 1 bulan, pasien merasakan adanya perbaikan secara klinis.
\end{abstract}

Kata kunci: kanker paru

\section{PENDAHULUAN}

Kanker paru dalam arti luas adalah semua penyakit keganasan di paru, mencakup keganasan yang berasal dari paru itu sendiri (primer) maupun keganasan dari luar paru (metastasis). Dalam pengertian klinis yang dimaksud dengan kanker paru primer adalah tumor ganas yang berasal dari epitel bronkus (karsinoma bronkus). ${ }^{1}$

Prevalensi kanker paru primer di negara maju sangat tinggi. Di USA tahun 2002 dilaporkan terdapat 169.400 kasus baru (merupakan $13 \%$ dari semua kanker baru yang terdiagnosis) dengan 154.900 kema- 
tian (merupakan 28\% dari seluruh kematian akibat kanker). Indonesia menduduki peringkat ke-4 kanker paru terbanyak di dunia. Tahun 1998 di Rumah Sakit (RS) Kanker Dharmais Jakarta kanker paru menduduki urutan ke-3 sesudah kanker payudara dan leher rahim. Angka kematian akibat kanker paru di seluruh dunia mencapai kurang lebih satu juta penduduk setiap tahunnya. Sebagian besar kanker paru mengenai laki-laki (65\%) life time risk 1:13 dan pada perempuan 1:20. Kelompok risiko tinggi ialah laki-laki dengan usia $>40$ tahun. ${ }^{1,2}$

Penyebab pasti dari kanker paru belum diketahui secara jelas. Paparan atau inhalasi berkepanjangan terhadap suatu zat yang bersifat karsinogenik merupakan faktor penyebab utama disamping adanya faktor lain seperti kekebalan tubuh, genetik dan lainlain. Dari beberapa kepustakaan telah dilaporkan bahwa etiologi kanker paru sangat berhubungan dengan kebiasaan merokok. Lombard dan Doering telah melaporkan tingginya insiden kanker paru pada perokok dibandingkan yang tidak merokok. ${ }^{2,3}$

Manifestasi klinis yang dapat ditemukan antara lain sesak nafas, batuk, nyeri dada, nyeri tulang belakang, hemoptisis, anoreksia, penurunan berat badan yang signifikan, lemah badan, dan obstruksi vena cava. Pembagian praktis berdasarkan hasil histopatologik terdiri atas small cell lung cancer (SCLC) dan non small cell lung cancer (NSCLC) yang terbagi atas karsinoma sel skuamosa, adenokarsinoma, karsinoma bronkoalveolar dan karsinoma sel besar. $^{2-4}$

Pemeriksaan penunjang yang dapat digunakan untuk mendiagnosis kanker paru antara lain pemeriksaan laboratorium, radiologi, trans thoracal biopsy (TTB), fine needle aspiration biopsy (FNAB), dan pemeriksaan histopatologik. ${ }^{5}$

Pengobatan kanker paru dibagi berdasarkan jenisnya antara NSCLC dan SCLC. Umumnya terapi yang diberikan berdasarkan stadium kanker itu sendiri, yaitu antara lain pembedahan, radioterapi, dan kemoterapi. Kemoterapi digunakan sebagai terapi baku untuk pasien kanker paru mulai dari stadium III A dan untuk pengobatan paliatif. ${ }^{5}$
Prevalensi kanker paru dan angka kematian masih tinggi di seluruh dunia. Laporan kasus ini membahas mengenai seorang pasien laki-laki dengan kanker paru yang sementara dalam kemoterapi dan menjalani perawatan di RSUP Prof. Dr. R. D. Kandou Manado.

\section{LAPORAN KASUS}

Seorang laki-laki Tn. HS, berusia 55 tahun, suku Bolaang Mongondow, sudah menikah, pekerjaan buruh, dengan alamat Lawangirung, LK. III, Kecamatan Wenang, Manado, Sulawesi Utara. Pasien datang ke instalasi gawat darurat (IGD) RSUP Prof. Dr. R. D. Kandou pada tanggal 24 Agustus 2018 dan selanjutnya dirawat di irina C1 dengan keluhan utama sesak nafas. Pada anamnesis terhadap pasien ini didapatkan keluhan sesak napas yang tidak dipengaruhi aktivitas sejak enam bulan lalu dan memberat satu minggu terakhir. Sesak nafas memberat dan tidak teratasi sejak 1 minggu terakhir, sehingga penderita datang ke IGD RSUP Prof. Dr. R. D. Kandou. Keluhan disertai dengan batuk sejak 6 bulan sebelum dirawat disertai lendir warna putihkekuningan, tidak bercampur darah. Pasien juga mengeluhkan nyeri punggung belakang sejak sekitar 6 bulan terakhir. Nyeri dirasakan hilang timbul dan berulang kali terjadi. Nyeri dada hilang timbul dirasakan 1 minggu sebelum dirawat, menjalar sampai punggung belakang dan dirasakan seperti ditusuk-tusuk. Penurunan berat badan secara nyata diakui penderita dalam waktu 6 bulan terakhir dari $65 \mathrm{~kg}$ turun menjadi 45 $\mathrm{kg}( \pm 20 \mathrm{~kg})$. Panas sumer-sumer hilang timbul sejak 1 minggu sebelum dirawat, panas turun dengan obat penurun panas. Mual dan muntah tidak dialami penderita. Penurunan nafsu makan yang disertai lemah badan sejak beberapa bulan terakhir. Tidak ada keluhan gangguan buang air besar dan buang air kecil. Pasien pernah dirawat sebelumnya di RSUP Prof. Dr. R. D. Kandou bulan April tahun 2018 dengan keluhan nyeri dada yang disertai sesak napas. Saat itu pada pasien dilakukan CT-Scan thorax dengan kontras dan tindakan Trans-thoracal biopsy (TTB). 
Riwayat terdiagnosis kanker paru sejak bulan November 2017 pada waktu dirawat di Rumah Sakit Siloam Manado. Saat itu pasien telah dilakukan pemeriksaan Multi Slice Computed Tomography (MSCT) scan Thorax tanpa dan dengan kontras yang memberi kesan kanker paru T4N3M1a, efusi pleura kanan, deviasi trakea ke kanan, efusi perikardium dan aortosklerosis. Pasien sudah ketiga kali ini masuk rumah sakit (MRS). Riwayat MRS sebelumnya bulan Maret 2018 dirawat di irina C4 dengan diagnosis tumor paru dekstra; bulan April 2018 dirawat di irina A bawah dengan diagnosis tumor paru dekstra suspek malignancy. Saat itu dilakukan trans-thoracal biopsy dan CT-scan thorax dengan kontras. Foto rontgen pasien pada tanggal 28 November 2017 memberi kesan curiga massa paru kanan. Pemeriksaan MSCT scan thorax irisan aksial tanpa dan dengan kontras tanggal 3 Maret 2018, memberi kesan suspek tumor lobus superior paru kanan dan tumor noduler lobus inferior paru kanan serta lobus inferior paru kiri (multipel), dan efusi pleura kanan minimal. Hasil echocardiography tanggal 14 Desember 2017 mendapatkan efusi perikardium minimal bagian posterior dan apeks sebesar $0,3 \mathrm{~cm}$. Hasil pemeriksaan histopatologik tanggal 14 April 2018 ialah adenocarsinoma dengan diagnosis banding bronchioloalveolar carcinoma. Berdasarkan hasil anamnesis, pemeriksaan fisik, dan beberapa pemeriksaan penunjang sebelumnya, pasien didiagnosis pasti sebagai kanker paru kanan dan diputuskan untuk dilakukan kemoterapi sejak tanggal 21 Juni 2018 di RS Siloam, Manado selama 12 siklus. Pasien sudah di kemoterapi sebanyak 6 kali dan terakhir kemoterapi satu bulan yang lalu tanggal 27 Juli 2018 dengan regimen gemcitabinecisplatin.

Riwayat sakit kencing manis, darah tinggi, kolesterol, asam urat disangkal. Penyakit hati, ginjal, jantung sebelumnya tidak ada. Pasien tidak memiliki riwayat mengonsumsi obat anti tuberkulosis (OAT) sebelumnya. Pasien memiliki riwayat kebiasaan merokok (sigaret) selama 10 tahun dengan jumlah \pm 15 batang rokok per hari.
Pasien mulai berhenti merokok sejak \pm 1 tahun terakhir, saat mulai bergejala batuk dan sesak nafas yang memberat. Riwayat penyakit keluarga, kedua orang tua pasien tidak memiliki riwayat keluhan yang sama atau keganasan lainnya serta tidak memiliki riwayat sakit kencing manis, darah tinggi, penyakit hati, penyakit ginjal dan jantung.

Pemeriksaan fisik didapatkan keadaan umum tampak sakit sedang, kesadaran kompos mentis dengan Glasgow coma scale (GCS) eye 4, verbal 5, motor 6 (E4V5M6), visual analog scale (VAS) 7, dengan tampilan umum penderita (Karnofsky score) yang menurun $60 \%$, tekanan darah 110/70 $\mathrm{mmHg}$, denyut nadi $100 \mathrm{x} / \mathrm{menit}$, teratur, isi cukup, frekuensi pernapasan $28 \mathrm{x} / \mathrm{menit}$, teratur, suhu badan aksiler $37,8^{\circ} \mathrm{C}, \mathrm{SpO} 298$ $\%$. Tinggi badan $160 \mathrm{~cm}$, berat badan $45 \mathrm{~kg}$, dan indeks massa tubuh (IMT) $17,57 \mathrm{~kg} / \mathrm{m}^{2}$, dengan kesan status gizi berat badan kurang. Konjungtiva tampak anemis, sklera tidak ikterik, pupil bulat isokor. Tidak ada lidah kotor dan faring tidak hiperemi. Terdapat pembesaran kelenjar di leher (supraklavikular kanan $\pm 2 \mathrm{~cm}$, kenyal, imobil). Trakea terletak di tengah, tidak ada peningkatan tekanan vena jugularis. Pada pemeriksaan dada, didapatkan pergerakan dinding dada simetris, fremitus raba di paru depan dan belakang kanan menurun setinggi intercostal space (ICS) V paru kanan dibandingkan paru kiri, sonor di kedua lapangan paru, suara pernapasan vesikuler, didapatkan ronki basah halus minimal pada basal paru bilateral, tidak terdengar wheezing pada kedua lapangan paru. Pada pemeriksaan jantung, iktus kordis tidak tampak dan tidak teraba pada sela iga $\mathrm{V}$ garis midklavikula kiri, batas jantung kanan pada linea sternalis kanan, batas jantung kiri pada sela iga $\mathrm{V}$ garis midklavikula kiri, suara jantung pertama dan kedua normal, teratur, tidak didapatkan bising jantung. Pada pemeriksaan abdomen tampak datar, lemas, peristaltik usus normal, tidak terdapat pembesaran hati dan limpa. Pada ekstremitas warna kulit normal, teraba hangat, dan tidak didapatkan edema.

Pemeriksaan laboratorium pada tanggal 24 Agustus 2018 mendapatkan kadar $\mathrm{Hb}$ 
$9,7 \mathrm{~g} / \mathrm{dL}$, hematokrit $28,4 \%$, leukosit $21.800 /$ $\mathrm{mm}^{3}$, trombosit $415.000 / \mathrm{mm}^{3}$, eri-trosit 3.30 x $10^{6} / \mu \mathrm{L}, \mathrm{MCH} 29,4 \mathrm{pg}, \mathrm{MCHC} 34,1 \mathrm{~g} / \mathrm{dL}$, MCV 86.3fL, SGOT 25 U/L, SGPT $12 \mathrm{U} / \mathrm{L}$, ureum $46 \mathrm{mg} / \mathrm{dL}$, kreatinin $1,1 \mathrm{mg} / \mathrm{dL}$, gula darah sewaktu $62 \mathrm{mg} / \mathrm{dL}, \mathrm{Na} 126 \mathrm{mEq} / \mathrm{L}, \mathrm{K}$ $4 \mathrm{mEq} / \mathrm{L}, \mathrm{Cl} 95 \mathrm{mEq} / \mathrm{L}$. Pemeriksaan foto toraks tanggal 23 Agustus 2018 memperlihatkan gambaran suspek tumor paru kanan, pneumonia, dan efusi pleura kanan. Pemeriksaan EKG ditemukan kesan normal.

Berdasarkan anamnesis, pemeriksaan fisik, serta pemeriksaan laboratorium dan penunjang lainnya, ditegakkan diagnosis kerja kanker paru kanan jenis adenokarsinoma dalam kemoterapi, penumonia, anemia pada malignancy, dan hiponatremia.

Terapi yang diberikan $\mathrm{O} 2$ nasal kanul 2 $4 \mathrm{~L} / \mathrm{menit}$, IVFD $\mathrm{NaCl}$ 0,9\% 20 tetes/menit, ceftriaksone 2 gram intravena tiap 24 jam, parasetamol $500 \mathrm{mg}$ peroral tiap $8 \mathrm{jam}, \mathrm{N}$ asetil sistein $200 \mathrm{mg}$ peroral tiap 8 jam, natrium bikarbonat $500 \mathrm{mg}$ peroral tiap 8 jam. Pasien direncanakan untuk pemeriksaan apusan darah tepi, darah lengkap, dan kontrol elektrolit. Pasien akan dilakukan transfusi darah packed red cell (PRC) sampai target $\mathrm{Hb} \geq 10 \mathrm{~g} / \mathrm{dL}$. Pasien dikonsulkan ke bagian Poliklinik Nyeri dan dilaporkan ke Divisi Hemato-Onkologi.

Hari kedua perawatan keadaan pasien masih sama dan terapi dilanjutkan. Hari ketiga perawatan pasien mengeluhkan nyeri dada menjalar sampai ke punggung. Keadaan umum sakit sedang, kesadaran kompos mentis. Tekanan darah 110/70 $\mathrm{mmHg}$, denyut nadi $80 \mathrm{x} / \mathrm{menit}$, frekuensi pernapasan $24 \mathrm{x} /$ menit, suhu badan aksiler $37^{\circ} \mathrm{C}$. Terapi ditambahkan analgetik ketorolak injeksi $30 \mathrm{mg}$ intravena tiap 8 jam, terapi lain masih dilanjutkan.

Hari keempat perawatan, keluhan nyeri dada menjalar sampai ke punggung belum teratasi. Mual, muntah, dan nyeri ulu hati. Keadaan umum sakit sedang, kesadaran kompos mentis. Tekanan darah 130/80 $\mathrm{mmHg}$, denyut nadi $92 \mathrm{x} / \mathrm{menit}$, frekuensi pernapasan $22 \mathrm{x} /$ menit, suhu badan aksiler $36,8^{\circ} \mathrm{C}$, dan VAS 8 . Pasien dikonsulkan ke Poliklinik Nyeri dan diberikan terapi analgetik opioid morfin SR $10 \mathrm{mg}$ peroral tiap 12 jam dengan parasetamol $500 \mathrm{mg}$ peroral tiap 8 jam. Monitor tanda-tanda depresi pernafasan. Terapi juga ditambahkan dengan ondansentron $8 \mathrm{mg}$ intravena tiap 8 jam dan lansoprazole $30 \mathrm{mg}$ peroral tiap 12 jam. Terapi injeksi ketorolak dihentikan, terapi lain tetap dilanjutkan.

Hari kelima perawatan, nyeri berkurang VAS < 7 , keadaan umum sakit sedang (membaik), kesadaran kompos mentis. Tekanan darah $120 / 80 \mathrm{mmHg}$, denyut nadi 80x/menit, frekuensi pernapasan 20x/menit, suhu badan aksiler $36,8^{\circ} \mathrm{C}$. Hasil pemeriksaan laboratorium $\mathrm{Hb} 7,7 \mathrm{~g} / \mathrm{dL}$, hematokrit $25,1 \%$, leukosit $17.000 / \mathrm{mm}^{3}$, trombosit $436.000 / \mathrm{mm}^{3}$, eritrosit $2,81 \times 10^{6} / \mu \mathrm{L}$, MCH 27,4 pg, MCHC 30,8 g/dL, MCV 89 $\mathrm{fL}, \mathrm{Na} 126 \mathrm{mEq} / \mathrm{L}, \mathrm{K} 3,33 \mathrm{mEq} / \mathrm{L}$, dan $\mathrm{Cl}$ $85,2 \mathrm{mEq} / \mathrm{L}$. Diagnosis kerja kanker paru kanan dalam kemoterapi, penumonia, anemia pada malignancy, hiponatremia, dan hipokalemia. Pasien direncanakan untuk dilakukan transfusi darah PRC. Terapi lain dilanjutkan dengan tambahan potasium clorida $600 \mathrm{mg}$ peroral tiap 24 jam.

Hari keenam perawatan, nyeri sudah tidak dirasakan lagi dan keluhan lain membaik. Keadaan umum sakit sedang (perbaikan), kesadaran kompos mentis. Tekanan darah 110/70 $\mathrm{mmHg}$, denyut nadi $80 \mathrm{x} /$ menit, frekuensi pernapasan $20 \mathrm{x} /$ menit, suhu badan aksiler $36,8^{\circ} \mathrm{C}$. Pasien diperiksa kembali darah lengkap setelah transfusi PRC. Terapi lain dilanjutkan.

Hari ketujuh perawatan, keluhan sudah tidak ada. Keadaan umum sakit sedang (perbaikan), kesadaran kompos mentis. Tekanan darah 120/80 mmHg, denyut nadi $80 \mathrm{x} /$ menit, frekuensi pernapasan $20 \mathrm{x} /$ menit, suhu badan aksiler $36,8^{\circ} \mathrm{C}$. Hasil pemeriksaan laboratorium terbaru $\mathrm{Hb} 11,1$ $\mathrm{g} / \mathrm{dL}$, hematokrit $35,5 \%$, leukosit $15.500 /$ $\mathrm{mm}^{3}$, trombosit $464.000 / \mathrm{mm}^{3}$, eritrosit $3,79 \times 10^{6} / \mu \mathrm{L}, \mathrm{MCH} 29,2 \mathrm{pg}, \mathrm{MCHC} 31,3$ g/dL, MCV 93,5 fL. Pasien direncanakan untuk rawat jalan dan kembali melanjutkan kemoterapi minggu depan di RS Siloam.

\section{BAHASAN}

Kanker paru merupakan penyebab utama kematian akibat keganasan di dunia, 
kira-kira 1/3 dari seluruh kematian akibat kanker pada laki-laki. Di Amerika Serikat, diperkirakan terdapat sekitar 213.380 kasus baru pada tahun 2007 dan 160.390 kematian akibat kanker paru. Hasil penelitian berbasis rumah sakit dari 100 RS di Jakarta memperlihatkan bahwa kanker paru merupakan kasus terbanyak pada laki laki dan nomor 4 terbanyak pada perempuan. Sebagian besar kanker paru mengenai lakilaki 1:13 dan pada perempuan 1:20. Kelompok risiko tinggi ialah laki-laki pada usia $>40$ tahun dibanding perempuan. Pada kasus ini pasien ialah seorang laki-laki dengan usia 55 tahun. ${ }^{1,2,5}$

Beberapa faktor risiko yang memengaruhi terjadinya kanker paru yaitu merokok, paparan terhadap bahan kimia yang bersifat karsinogen (asbes dan radon), riwayat keluarga, genetik, faktor terkait dengan jenis kelamin, diet, dan penyakit penyerta lainnya. Diperkirakan terdapat metabolit dalam asap rokok yang bersifat karsinogen terhadap organ tubuh tersebut. Zat-zat yang bersifat karsinogen (C), kokarsinogenik (CC), tumor promotor (TP), mutagen (M) telah dibuktikan terdapat dalam rokok. Terdapat perubahan/mutasi beberapa gen yang berperanan dalam kanker paru, yakni: proto oncogen, tumor supressor gene, dan gene encoding enzyme. Terjadinya kanker paru didasari dari perubahan tampilnya gen supresor tumor dalam genom (onkogen). Selain sebagai inisiator, rokok juga merupakan promotor dan progresor dan rokok diketahui sangat berkaitan dengan terjadinya kanker paru. Dengan demikian kanker merupakan penyakit genetik yang pada permulaan terbatas pada sel sasaran kemudian menjadi agresif pada jaringan sekitamya bahkan mengenai organ lain. ${ }^{2,6}$ Pada kasus ini pasien memiliki riwayat kebiasaan merokok (sigaret) selama 10 tahun sebanyak \pm 15 batang rokok/hari.

Kanker paru memberikan manifestasi klinis berdasarkan tempat kejadian. Untuk tumor yang tumbuh setempat (lokal/ primer) manifestasi dapat berupa hemoptisis, kehilangan berat badan yang nyata, penurunan nafsu makan, sesak nafas, nyeri pada dada dan punggung, kelelahan/kelemahan badan dan batuk. Kanker paru dengan penyebaran intratorakal memberikan gejala seperti penurunan suara nafas dan sesak nafas, penurunan suara jantung disertai pembesaran jantung, kesulitan menelan, peninggian diafragma, pembengkakan wajah, edema ekstremitas, suara serak, batuk yang jarang, nyeri dada pleura, ptosis, miosis, facial anhidrosis, serta nyeri pun-gung dan otot sepanjang servikal 8 - torakal 3. Kanker yang sudah bermetastase jauh biasanya ditandai dengan kelemahan, penurunan berat badan, anoreksia, hepatomegali, nyeri, fraktur pada tulang, peningkatan alkalin fosfatase, limfadenopati, nyeri kepala, kejang, mual, muntah, perubahan status mental, insufisiensi adrenal, dan nodul subkutan. Pada pasien ini ditemukan gejala seperti sesak nafas, batuk, nyeri dada menjalar sampai ke punggung, adanya pembesaran kelenjar getah bening subklavikular kanan, penurunan suara nafas paru kanan, dan peninggian diafragma. Pasien juga mengalami penurunan berat badan yang nyata sehingga kanker pada kasus ini dicurigai sudah bermetastasis. ${ }^{2,4}$

Beberapa pemeriksaan yang dapat dilakukan untuk mendiagnosis suatu kanker paru antara lain berupa foto toraks dan histopatologi. Antara tahun 1970 dan 1980, telah dilakukan beberapa uji coba yang mempelajari foto toraks dan analisis sitologi dahak untuk mendeteksi kanker paru. Dalam dekade-dekade itu, program Mayo Lung dan uji coba Johns Hopkins dirancang untuk mengevaluasi apakah pemeriksaan foto toraks dan sitologi dahak akan meningkatkan deteksi dini pada kanker paru dan mengurangi mortalitas pada individu yang berisiko tinggi. Kedua studi ini menunjukkan deteksi dini pada kanker paru dengan metode skrining Kohort, meskipun keduanya gagal menunjukkan penurunan mortalitas dari kasus kanker paru. ${ }^{7,8}$

Berdasarkan pada studi percobaan Prostate, Lung, Colorectal and Ovarian Cancer (PLCO), tinjauan sistematis Cochrane baru-baru ini tentang skrining untuk kanker paru menyimpulkan bahwa computed tomography (CT) lebih bermanfaat dari pada rontgen dada, terutama untuk perokok beri- 
siko tinggi. Pemeriksaan foto rontgen dada dengan cara tomografi lebih akurat menunjang kemungkinan adanya tumor paru, bila dengan cara foto dada biasa tidak dapat memastikan keberadaan tumor. Pemeriksaan CT Scan pada toraks lebih sensitif daripada pemeriksaan foto dada biasa, karena bisa mendeteksi kelainan atau nodul dengan diameter minimal $3 \mathrm{~mm}$, walaupun positif palsu untuk kelainan sebesar itu mencapai 25-60\%. Pemeriksaan penunjang radiologis lain yang kadang-kadang diperlukan juga ialah bronkografi, fluoroskopi, superior vena cavography, ventilation/perfusion scanning, dan ultra-sound sonography. ${ }^{9}$

Pemeriksaan bone scanning diperlukan bila diduga ada tanda-tanda metastasis ke tulang. Pemeriksaan sitologi sputum dianjurkan sebagai pemeriksaan rutin dan skrining. Pemeriksaan sitologi lain untuk diagnosis kanker paru dapat dilakukan pada cairan pleura, aspirasi kelenjar getah bening servikal dan supraklavikular, serta bilasan dan sikatan bronkus pada bronkoskopi. Untuk diagnosis dini kanker paru, pemeriksaan histopatologik merupakan baku emas. Diagnosis kanker paru untuk mendapatkan spesimennya dapat dengan cara biopsi melalui: bronkoskopi, trans torakal biopsi, torakskopi, mediastinoskopi, dan torakotomi. Biopsi dengan TTB terutama untuk lesi yang letaknya perifer dengan ukuran $>2$ $\mathrm{cm}$ sensitivitasnya mencapai $90-95 \%$. Hasil pemeriksaan akan lebih baik bila ada tuntunan CT Scan, USG, atau fluoroskopi. ${ }^{2,7}$

Untuk pemeriksaan serologik/tumor marker sampai saat ini belum ada pemeriksaan serologi penanda tumor untuk diagnosis kanker paru yang spesifitasnya tinggi. Beberapa tes yang dipakai ialah: 1) carcinoma embryonic antigen (CEA); 2) neuron-spesific enolase (NSE); dan 3) cytokeratin 19-fragments (Cyfra 21-1). Pada pasien ini awalnya dilakukan pemeriksaan foto toraks yang menandakan adanya massa pada paru kanan. Pemeriksaan MSCT thorax tanpa dan dengan kontras memberi kesan kanker paru kanan T4N3M1a, efusi pleura kanan, deviasi trakea ke kanan, efusi perikardium dan aortosklerosis. Pemeriksaan MSCT thorax irisan axial tanpa dan dengan kontras memberi kesan suspek tumor lobus superior paru kanan dan tumor noduler lobus inferior paru kanan serta lobus inferior paru kiri (multipel) dengan efusi pleura kanan minimal. Melalui trans torakal biopsi, dilakukan pemeriksaan histopatologik yang memberikan hasil adenokarsinoma dd brochioloalveolar carcinoma. $^{2}$

Diagnosis kanker paru didapatkan dari anamnesis lengkap, pemeriksaan fisik, darah lengkap, foto thoraks, CT scanthorax, analisis dahak dapat membantu dalam kasus lesi sentral. Bone scanning, FNA transthoracic perkutan dapat dilakukan dengan bimbingan $\mathrm{CT}$ atau bimbingan fluoroskopik. Pada pasien ini diagnosis pasti didapatkan dari anamnesis lengkap, pemeriksaan fisik, pemeriksaan radiologik dan histopatologik. Diagnosis pasti pada pasien ini ialah kanker paru kanan (adenokarsinoma). ${ }^{10,11}$

Stadium kanker paru dapat ditentukan secara diagnosis klinis (cTNM), reseksi surgikal-patologis (pTNM), evaluasi surgikal (sTNM), retreatment (rTNM), dan autopsi (aTNM). Untuk staging kanker paru, sedikitnya diperlukan pemeriksaan $C T$ Scan toraks, USG abdomen (atau CT scan abdomen), serta $C T$ scan otak dan bone scanning. Untuk keterangannya Tx: 1) Tumor terbukti ganas didapat dari sekret bronkopulmoner, tetapi tidak terlihat secara bronkoskopis dan radiologis; 2) Tumor tidak bisa dinilai pada staging retreatment. Tis: carcinoma in situ (pre invasive carcinoma), T1: tumor, diameter $<3 \mathrm{~cm}, \mathrm{~T} 2$ : tumor, diameter $>3 \mathrm{~cm}$ atau terdapat atelektasis pada distal hilus. T3: tumor ukuran apapun meluas ke pleura, dinding dada, diafragma, perikardium, $<2 \mathrm{~cm}$ dari carina, terdapat atelektasis total. T4: tumor ukuran apapun invasi ke mediastinum atau terdapat efusi pleura malignan. No: tidak ada kelenjar getah bening (KGB) yang terlibat, N1: metastasis kelenjar getah bening (KGB) bronkopulmoner atau ipsilateral hilus. N2: metastasis KGB mediastinal atas sub carina. N3: metastasis KGB mediastinal kontra lateral atau hilus atau KGB skaleneus atau supraklavikular. Mo: tidak ada metastasis jinak, Ml: metastasis 
jinak pada organ (otak, hati, tulang dsb). ${ }^{10,11}$

Pada pasien ini ditentukan staging yaitu T4N3M1a. T4 karena dari gambaran MSCT toraks dengan rekonstruksi aksial didapatkan massa batas kurang tegas tepi ireguler pada lobus superior paru kanan 9x7,4x6,1 cm mengobliterasi bronkus kanan superior, meluas ke kavum mediastinum dengan adanya efusi pleura kanan. N3 karena didapatkan pembesaran kelenjar getah bening multipel subkarina pada regio subklavikula kanan (ukuran terbesar $\pm 2,5 \mathrm{~cm}$ ). M1 karena curiga sudah ada metastasis jinak pada mediastinum. ${ }^{2,5}$

Tujuan pengobatan kanker di antaranya ialah: secara kuratif, untuk menyembuhkan atau memperpanjang masa bebas penyakit dan meningkatkan angka harapan hidup pasien; paliatif, untuk mengurangi dampak kanker dan meningkatkan kualitas hidup; rawat rumah (hospice care) pada kasus terminal: mengurangi dampak fisik maupun psikologis kanker baik pada pasien maupun keluarga; suportif, menunjang pengobatan kuratif paliatif dan terminal seperti pemberian nutrisi, transfusi darah dan komponen darah, growth factors, obat anti nyeri, dan obat anti infeksi. ${ }^{6}$

Pembagian praktis kanker paru berdasarkan pemeriksaan histopatologik meliputi SCLC dan NSCLC yang terbagi atas karsinoma sel skuamosa, adenokarsinoma, karsinoma bronkoalveolar dan karsinoma sel besar. ${ }^{2-4,6,11}$ Pada pasien ini tergolong NSCLC karena pada pemeriksaan histopatologik didapatkan hasil adenokarsinoma dengan diagnosis banding bronchioloalveolar carcinoma.

Terdapat perbedaan fundamental biologis antara NSCLC dan SCLC, sehingga pengobatannya harus dibedakan. Pengobatan NSCLC antara lain berupa terapi bedah yang merupakan pilihan pertama pada stadium I atau II pada pasien dengan sisa cadangan parenkim parunya yang adekuat. Pada stadium III A masih ada kontroversi mengenai keberhasilan operasi bila kelenjar mediastinum ipsilateral atau dinding torak terdapat metastasis. Pasien stadium III b dan IV tidak dilakukan operasi melainkan kemoterapi. Prinsip kemoterapi ialah sel kanker memiliki sifat perputaran daur sel lebih tinggi dibandingkan sel normal, dengan demikian tingkat mitosis dan proliferasinya tinggi. Sitostatika kebanyakan efektif terhadap sel yang bermitosis. ${ }^{2,5,8,10,11}$

Terdapat beberapa hal yang dapat memengaruhi kegagalan pencapaian target pengobatan antara lain: 1) resistensi terhadap sitostatika; 2) penurunan dosis sitostatika dimana penurunan dosis sebesar $20 \%$ akan menurunkan angka harapan sembuh sekitar 50\%; 3) penurunan intensitas obat dimana jumlah obat yang diterima selama kurun waktu tertentu kurang. Untuk mengatasi hal tersebut, dosis obat harus diberikan secara optimal dan sesuai jadwal pemberian. Penggunaan regimen kemoterapi agresif (dosis tinggi) harus didampingi dengan rescue sel induk darah yang berasal dari sumsum tulang atau darah tepi yang akan menggantikan sel induk darah akibat mieloablatif. Penilaian respon pengobatan kanker dapat dibagi menjadi 5 golongan seperti: 1) remisi komplit, tidak tampak seluruh tumor terukur atau lesi terdeteksi selama lebih dari 4 minggu; 2) remisi parsial, tumor mengecil $>50 \%$ tumor terukur atau $>50 \%$ jumlah lesi terdeteksi menghilang; 3) stable disease pengecilan $50 \%$ atau <25\% membesar; 4) progresif tampak beberapa lesi baru atau $>25 \%$ membesar; 5). lokoprogresif tumor membesar di dalam radius tumor (lokal). ${ }^{2,3,5,10}$

Penggunaan kemoterapi pada pasien NSCLC dalam dua dekade terakhir ini sudah diteliti. Untuk pengobatan kuratif kemoterapi dikombinasikan secara terintegrasi dengan modalitas pengobatan kanker lainya pada pasien dengan penyakit lokoregional lanjut. Kemoterapi digunakan sebagai terapi baku untuk pasien mulai dari stadium III dan untuk pengobatan paliatif. Kemoterapi neoadjuvan diberikan mulai dari stadium II dengan sasaran lokoregional tumor dapat direseksi lengkap. Cara pemberian ialah setelah terapi lokal. Terapi definitif dengan pembedahan, radioterapi, atau keduanya diberikan di antara siklus pemberian kemoterapi. Untuk pemilihan obat, kebanyakan obat sitostatik mempunyai aktivitas cukup baik pada NSCLC dengan tingkat respons 
antara $15-33 \%$, walaupun demikian penggunaan obat tunggal tidak mencapai remisi komplit. Kombinasi beberapa sitostatik telah banyak diteliti untuk meningkatkan tingkat respon yang akan berdampak pada harapan hidup. Mula-mula regimen yang terdiri dari siklofosfamid, doksorubisin, metotreksat dan prokarbasin (CAMP) dengan tingkat respon regimen ini $26 \%$. Obat lain yang baru saat ini telah banyak dihasilkan dan dicobakan sebagai obat tunggal seperti paclitaxel, docetaxsel, vinorelbine, gemcitabine, dan irenotecan dengan hasil yang cukup menjanjikan, begitu juga bila dimasukkan ke regimen lama membentuk regimen baru. Kemoterapi adjuvan dengan atau tanpa radioterapi, mula-mula yang dikembangkan ialah protokol CAP (siklofosfamid, doksorubisin, dan cisplatin). Hasil penggunaan terapi biologi seperti BCG, levamisole, interferon dan interleukin dengan kombinasi modalitas lainnya masih kontroversial. Mengenai terapi gen, akhirakhir ini dikembangkan penyelarasan gen (Chimeric) dengan cara transplantasi sel stem alogenik dari darah tepi maupun sumsum tulang. Pada pasien ini karena sudah masuk dalam stadium IV maka pilihan terapi ialah kemoterapi dengan regimen kombinasi yakni gemcitabinecisplatin selama 12 siklus. ${ }^{2,3,5,11,12}$

Pada prognosis kasus NSCLC, yang terpenting ialah menentukan stadium penyakit. Sekitar 40\% adenokarsinoma dan karsinoma sel besar meninggal akibat komplikasi torakal, 55\% karena ekstra torakal, $15 \%$ adenokarsinoma dan karsinoma sel besar bermetastasis ke otak, dan 8-9\% meninggal karena kelainan sistem saraf sentral. Rerata harapan hidup pasien dengan tumor metastasis bervariasi, dari 6 bulan sampai dengan 1 tahun. Hal ini sangat tergantung pada performance status (skala Karnofsky), luasnya penyakit, dan adanya penurunan berat badan dalam 6 bulan terakhir. ${ }^{10-12}$ Prognosis pada pasien ini untuk vitam ialah dubia ad malam karena kemungkinan komplikasi kanker itu sendiri yang sudah bermetastase dapat mengancam nyawa dari pasien. Untuk functionam ialah dubia ad malam, karena dalam melakukan aktivitas sehari-hari memerlukan bantuan orang lain, dalam arti sudah tidak dapat melakukan aktivitas secara mandiri. Untuk ad sanactionam ialah dubia, karena kemungkinan untuk ukuran sel kanker membesar dan bermitosis dapat terjadi.

Pencegahan yang paling penting ialah tidak merokok sejak usia muda. Berhenti merokok dapat mengurangi risiko terkena kanker paru. Akhir-akhir ini pencegahan dengan chemoprevention banyak dilakukan, yakni dengan memakai derivat asam retinoid, karotenoid, vitamin $\mathrm{C}$, selenium, dan lain-lain. ${ }^{2,3}$

\section{SIMPULAN}

Telah dilaporkan sebuah kasus kanker paru pada seorang laki-laki berusia 55 tahun. Diagnosis ditegakkan berdasarkan anamnesis, pemeriksaan fisik, dan pemeriksaan penunjang. Pemeriksaan penunjang foto toraks, CT-scan toraks, dan histopatologik menyokong diagnosis suatu kanker paru (adenokarsinoma).

Penatalaksanaan pasien ini ialah pemberian terapi kemoterapi dengan kombinasi regimen gemcitabine-cisplatin selama 12 siklus. Prognosis pasien ini buruk karena sudah sampai pada stadium 4, namun dengan kemoterapi yang sementara dijalani sampai saat ini selama 1 bulan, pasien merasakan adanya perbaikan secara klinis.

\section{DAFTAR PUSTAKA}

1. Panduan Praktik Klinis Kanker Paru, Komite Penanggulangan Kanker Nasional, tahun 2015

2. Zulkifli A. Kanker Paru. Buku Ajar Ilmu Penyakit Dalam Jilid III (6th ed). Jakarta: Pusat Penerbitan Ilmu Penyakit Dalam, 2014.

3. Doherty MG, editor. Current Diagnosis and Treatment (14th ed). Mc Graw Hill Lange, 2015; p. 1582-86.

4. Kelly M, Latimer, Timothy F. Lung Cancer: Diagnosis, Treatment, Principles, and Screening. Florida. 2015: 251-55

5. Leora H, Chritin M, David J. Neoplasm of the lung. In: Harrison's Principles of Internal Medicine (19the ed). USA: Mc Graw Hill, 2015; p. 506-23.

6. Gouvinhas C, De Mello RA, Oliveira D, Castro- 
Lopez JM, Castelo-Branco P, Dos Santor RS, et al. Review lung cancer: a brief review of epidemiology and screening. Future Oncology. 2018; 14(6):567-75.

7. Doria-Rose VP, Marcus PM, Szabo E, Tockman MS, Melamed MR, Prorok PC. Randomized controlled trials of the efficacy of lung cancer screening by sputum cytology revisited: a combined mortality analysis from the Johns Hopkins Lung Project and the Memorial Sloan-Kettering Lung Study. Cancer. 2009;115(21):5007-17.

8. Fontana RS, Sanderson DR, Woolner LB, Taylor WF, Miller WE, Muhm JR. Lung cancer screening: the Mayo program. J Occup Med. 1986; 28(8):746-50.

9. Manser R, Lethaby A, Irving LB, Stone C, Byrnes G, Abramson M, Campbell D.
Screening for lung cancer. Cochrane Database Syst. Rev. 2013;21(6): doi: 10.1002/14651858. CD001991.pub3.

10. Anish T, Christina B, Giuseppe G. Non-small cell lung cancer. In: Abraham J, Gulley JL, Allegra CJ, editors. The Bethesda Handbook of Clinical Oncology (4th ed). LWW, 2014; p. 31-42

11. Ettinger DS, Eood DE, Aisner DL, Akerley W, Bauman J, Camidge DR, et al. Non small-cell lung cancer Version 2.2018. NCCN Clinical Practice Guidelines in Oncology (NCCN Guidelines), 2017.

12. DeVita VT, Lawrence TS, Rosenberg SA, editors, Rosenberg's Cancer: Principles $\&$ Practice of Oncology (Cancer Principles \& Practice of Oncology) (10th ed). Wolters Kluwers Health, 2015; p. 512. 